\title{
Analisis dan Perancangan Layanan Aspirasi Dan Informasi Pada Kelurahan Oebufu
}

\author{
Olivia Maria Inacio Tavares \\ Sistem informasi STIKOM Uyelindo Kupang \\ Email: tavaresolivia256@gmail.com
}

\begin{abstract}
ABSTRAK
Saat ini peranan teknologi informasi dalam membantu memajukan efisiensi kerja lembaga pemerintahan sudah sangat berkembang pesat mulai dari kantor pemerintahan di daerah perkotaan hingga pada pelosok-pelosok daerah kecil. Setiap instansi pemerintah dituntut untuk dapat mengelola dengan baik sistem kerja yang dijalankan, terutama dalam pengelolaan sistem informasi secara lengkap, terstruktur, serta transparan kepada masyarakat sehingga kebutuhan akan informasi oleh setiap pihak yang berkepentingan dapat terpenuhi dengan baik, lengkap, cepat serta bisa ditemukan dimana saja dan kapan saja. Dalam menanggapi hal ini, di Kelurahan Oebufu, Kota Kupang, Nusa Tenggara Timur belum terdapat sarana yang dapat menginformasikan berbagai bentuk layanan, program serta informasi terkait kelurahan sehingga masyarakat masih kesulitan dalam mengetahui berbagai informasi penting terkait kelurahan. Selain masalah penyebaran informasi di kelurahan, masyarakat juga kesulitan dalam menyampaikan berbagai bentuk aspirasi ataupun keluhan tentang berbagai masalah, baik masalah sampah, kondisi sosial masyarakat dan lain sebagainya. Dikarenakan hal tersebut maka akan dirancang sebuah sistem yang berbasis Android dan SMS gateway dengan memanfaatkan web service sebagai sarana penyampaian aspirasi dan informasi guna memudahkan pihak kelurahan maupun masyarakat Kelurahan Oebufu dalam hal penyebaran dan pengaksesan informasi serta penyampaian dan penanggapan aspirasi.

Kata kunci: Android, aspirasi, informasi, layanan, SMS gateway, web service.
\end{abstract}

\section{PENDAHULUAN}

Di era yang menuntut informasi yang cepat dan tepat, teknologi informasi tentunya memiliki peranan yang sangat besar dalam memudahkan fungsi kerja instansi pemerintahan seiring dengan kebutuhan yang berhubungan dengan pelayanan terhadap masyarakat dengan terciptanya tata kelola pemerintahan yang baik (good governance) salah satunya tercermin pada kualitas pelayanan publik yang diberikan pada masyarakat. Melalui pemberian pelayanan yang baik tentunya akan memberikan nilai positif dan menciptakan dukungan terhadap cerminan kinerja pemerintahan yang bersih dan berkualitas. Apabila melalui bentuk pelayanannya, aparat pemerintah mampu menciptakan suasana yang kondusif dengan masyarakat maka kondisi tersebut dapat dikategorikan sebagai keadaan yang mengarah pada terselenggaranya asas-asas good governance [1].

Melalui implementasi teknologi informasi tentunya banyak memberikan kontribusi yang sangat berarti dalam meningkatkan kinerja instansi pemerintahan. Dalam susunan peraturan untuk kinerja sistem kepemerintahan Negara Kesatuan Republik Indonesia yang diatur dalam UndangUndang Nomor 5 Tahun 2014 dituliskan bahwa kinerja instansi yang terbaik dapat mencerminkan kualitas pemerintahan yang semakin maju dan berkembang dengan berbagai kemudahan dalam melaksanakan aktivitas fungsi kerja maupun tanggung jawab instansi, dimana dalam hal ini dapat dengan cepat dan tepat mengambil keputusan untuk memajukan kinerjanya.

Dari berbagai hal tersebut maka setiap instansi pemerintah dituntut untuk dapat mengelola dengan baik sistem kerja yang tengah dijalankan, terutama dalam hal pengelolaan sistem informasi secara lengkap, terstruktur, serta transparan kepada masyarakatnya, sehingga kebutuhan akan informasi oleh setiap pihak yang berkepentingan dapat terpenuhi dengan baik, cepat serta dapat ditemukan dimana saja dan kapan saja.

Adapun dalam setiap perkembangan yang terjadi di Kelurahan Oebufu, Kota Kupang, Nusa Tenggara Timur selalu berdasar pada aspirasi dari masyarakatnya, dalam uraian tugas dan fungsi kerja kepemerintahan Kelurahan Oebufu salah satunya yaitu menciptakan pelayanan dan koordinasi yang baik dengan mendengarkan aspirasi dari masyarakat, selain itu untuk tugas dan fungsi setiap seksi yang mana harus siap sedia menyiapkan berbagai kebutuhan masyarakat baik dari segi kebutuhan sosial maupun kebutuhan akan fasilitas guna meningkatkan kinerja kepemerintahan pada kelurahan terkait.

Terkait hal tersebut, Kelurahan Oebufu masih belum memiliki sarana yang dapat 
menginformasikan berbagai layanan, program serta informasi terkini dari kelurahan kepada masyarakat dan sebaliknya masyarakat juga belum memiliki sarana untuk menyampaikan aspirasinya kepada pihak kelurahan. Oleh karena itu diperlukan penerapan sistem layanan aspirasi dan informasi. Akan tetapi, penerapan sistem tersebut tidak akan bisa dilakukan jika tanpa perencanaan infrastruktur dan perancangan sistem yang tepat, karena dengan perencanaan infrastruktur dan perancangan sistem yang tepat diharapkan dapat meminimalkan atau bahkan meniadakan kerugian organisasi/instansi pemerintahan [2].

Berdasarkan permasalahan yang terjadi dan mengingat pentingnya ketersediaan layanan aspirasi dan informasi guna menunjang kinerja pemerintahan maka pada penelitian ini akan dilakukan analisis dan perancangan sistem layanan yang dimaksud guna menjadi dasar untuk pembangunan dan penerapan sistem tersebut ke depannya. Adapun sistem yang akan dirancang terdiri dari 2 (dua) aplikasi yaitu aplikasi android berbasis web service dan SMS gateway.

\section{LANDASAN TEORI}

\section{Layanan}

Layanan yaitu suatu usaha untuk membantu menyiapkan atau mengurus apa yang diperlukan orang lain [3]. Layanan juga diartikan sebagai suatu tindakan sukarela dari satu pihak ke pihak lain dengan tujuan membantu atau adanya permintaan kepada pihak lain untuk memenuhi kebutuhannya secara sukarela [4].

Pelayanan merupakan aspek yang tidak bisa disepelekan dalam persaingan manapun dikarenakan melalui pelayanan yang terbaik masyarakat maupun konsumen akan menilai kemudian menimbang apakah selanjutnya akan loyal pada pemberi layanan tersebut hingga tak jarang para pebisnis ataupun instansi pemerintahan memaksimalkan layanannya untuk menarik dan memuaskan konsumen dan masyarakat.

Beberapa ciri pelayanan yang baik yang dapat memberikan kepuasan pada pihak yang dilayani, dalam konteks ini adalah masyarakat yaitu:

a. Memiliki karyawan atau pegawai yang professional khususnya yang berhadapan langsung dengan masyarakat.

b. Tersedianya sarana dan prasarana yang baik serta dapat menunjang kelancaran program kepada masyarakat secara cepat dan tepat.

c. Bertanggung jawab kepada masyarakat dari awal hingga selesai, serta mampu membangun komunikasi yang baik dengan masyarakat yang dilayani.

2. Aspirasi
Aspirasi berawal dari kata aspire, yang artinya bercita-cita atau menginginkan. Aspirasi merupakan harapan dan tujuan untuk keberhasilan pada masa yang akan datang [5]. Selain itu, aspirasi juga dapat diartikan sebagai harapan atau keinginan individu akan suatu keberhasilan atau prestasi tertentu [6]. Aspirasi didefinisikan sebagai keinginan yang kuat dan usaha yang dilakukan untuk meraih sesuatu yang lebih tinggi dari keadaan sekarang. Keinginan tersebut dapat berupa keinginan meningkatkan status individu, maupun keinginan yang tidak wajar dan terlalu berani.

\section{Informasi}

Informasi didefinisikan sebagai data yang telah diatur sehingga memiliki makna dan nilai bagi penerimanya [7] atau juga merupakan data yang telah diproses, atau data yang memiliki arti dimana sumber dari informasi adalah data [8]. Adapun kualitas dari informasi dimana saat ini sangat dipengaruhi oleh 3 (tiga) hal penentu antara lain:

a. Akurat

Berarti informasi harus bebas dari kesalahankesalahan dan tidak bias atau menyesatkan. Akurat juga berarti informasi harus jelas, nyata (real) tercerminkan maksudnya. Informasi harus akurat karena dari sumber informasi sampai ke penerima informasi kemungkinan terjadi gangguan yang dapat merubah atau merusak informasi menjadi informasi yang bersifat palsu (hoax).

b. Tepat Waktu

Berarti informasi yang datang pada penerima tidak boleh terlambat/lama. Informasi yang sudah usang tidak akan mempunyai nilai lagi karena informasi merupakan landasan dalam pengambilan keputusan. Bila pengambilan keputusan terlambat, maka dapat berakibat fatal bagi organisasi. Saat ini mahalnya nilai informasi disebabkan karena harus cepatnya informasi didapat sehingga diperlukanlah bantuan implementasi teknologi guna menunjang penyaluran informasi terkini dan ter-up to date.

c. Relevan

Informasi mempunyai manfaat besar untuk pemakainya. Relevansi suatu informasi untuk tiap orang satu dengan yang lainnya, misalnya informasi mengenai sebab kerusakan mesin produksi tidak boleh ditangani secara sembarang tetapi harus ditangani ahlinya karena setiap informasi memiliki relefansi yang berbeda.

\section{Android}

Android adalah sebuah sistem operasi untuk perangkat mobile berbasis linux yang mencakup sistem operasi, middleware, dan aplikasi. Di dunia ini terdapat dua jenis distributor sistem operasi Android. Pertama yang mendapat dukungan penuh dari Google atau Google Mail Services (GSM) dan kedua adalah yang bebas distribusinya tanpa dukungan Google atau Open Handset Distribution (OHD).

Pada saat ini kebanyakan vendor smartphone memproduksi smartphone berbasis Android, antara 
lain HTC, Motorola, Samsung, LG, Sony Ericsson, Acer, Nexus, Nexian, IMO, dan masih banyak lagi [9].

Adapun media untuk pembuatan aplikasi android yang sering digunakan yaitu Android Studio. Yang dimana dijelaskan dalam [10], Android Studio merupakan Software Integrated Development Environment (IDE) yang resmi untuk membangun aplikasi android. Android Studio dibangun berdasarkan IntelliJ IDEA yang merupakan software integrated development enviroment untuk membangun aplikasi atau software dengan bahasa pemrograman Java.

\section{SMS Gateway}

SMS gateway merupakan jenis aplikasi SMS dua arah, dengan keunikan semua tarif yang diperlakukan adalah tarif SMS normal sesuai dengan apa yang diperlakukan oleh operator. Karena sifatnya yang dua arah, maka jenis SMS ini sangat cocok dijadikan sebagai SMS center organisasi atau institusi tertentu [11]. SMS gateway merupakan komunikasi dua arah, mengirim dan menerima, digunakan untuk SMS keyword, polling ataupun informasi lainnya [12].

Mekanisme SMS gateway mulai dari mengirim dan menerima pesan singkat berupa teks melalui sebuah komputer yang terhubung ke handphone atau modem GSM melalui serial port. Dimana handphone berfungsi sebagai modem. Arsitekur ini disebut independent service. Arsitektur lain untuk menghubungkan antara penerima dan penyedia informasi melalui SMS yaitu dependent service, dimana komputer yang berfungsi server gateway terhubung secara langsung ke server operator seluler melalui internet [13].

SMS gateway menjadi pintu gerbang bagi penyebaran informasi melalui media SMS. Dengan SMS gateway pengguna dapat menyebarkan pesan ke beberapa nomor secara otomatis dan cepat tanpa harus mengetik pesan berulang kali. Pengguna cukup memasukkan nomor tujuan ke dalam suatu database. SMS gateway memudahkan pengguna untuk membuat pesan broadcast, announcement, reminder, voting, dan polling. Cara kerja SMS gateway sama dengan cara kerja SMS pada umumnya, hanya berbeda dalam hal perangkat. SMS gateway, perangkat pengirimannya bukan lagi perangkat telepon genggam, melainkan modem menggunakan jaringan provider [14].

\section{Web Service}

Web service adalah aplikasi sekumpulan data (database), perangkat lunak (software) atau bagian dari perangkat lunak yang dapat diakses secara remote oleh berbagai piranti dengan sebuah perantara tertentu. Web service dapat diartikan juga sebagai sebuah metode pertukaran data, tanpa memperhatikan struktur dari database yang dibangun, dibuat dalam bahasa pemrograman guna melaksanakan fungsi yang spesifik yang dibutuhkan pada sistem. [15]. Selain itu, web service dijelaskan sebagai aplikasi perangkat lunak yang dapat ditemukan, diuraikan, dan diakses berdasarkan pada XML dan protokol standard web pada intranet, extranet, dan internet [16]. Web service menyediakan berbagai standar komunikasi di antara berbagai aplikasi software yang berbeda, dan dapat berjalan di berbagai platform maupun framework [17].

Web service digunakan sebagai suatu fasilitas yang disediakan oleh suatu web untuk menyediakan layanan kepada sistem lain, sehingga dapat berinteraksi dengan sistem tersebut melalui layanan (service) yang disediakan sistem yang menyediakan web service [18]. Dalam hal ini web service menjadi suatu media yang menjembatani pertukaran data dari aplikasi android yang akan dibangun.

\section{METODE}

Walaupun dalam penelitian ini hanya terbatas pada analisis dan perancangan sistem, akan tetapi fase-fase yang dilakukan disesuaikan berdasarkan metode Global eXtreme Programming (GXP). R. Ferdiana mendefinisikan metode GXP dalam bukunya Rekayasa Perangkat Lunak yang Dinamis dengan Global eXtreme Programming, sebagai suatu metode yang menekankan pada komunikasi yang intens antara pihak klien dan tim, berdasarkan pengembangan yang efisien melalui model pengujian yang intens, hingga model yang iteratif dan incremental.

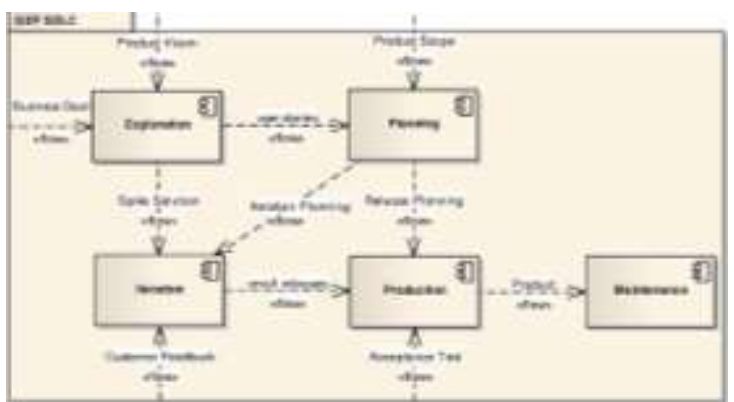

Gambar 1. Metode Global eXtreme Programming

Lima fase GXP adalah Exploration, Planning, Iteration, Production, and Maintenance. Setiap fase akan mengelola masukan dan menghasilkan keluaran untuk dikelola pada fase selanjutnya. Berikut rinciannya:

a. Exploration phase (Fase eksplorasi)

Pada fase ini difokuskan dalam penyamaan visi antara pengembang dengan klien, identifikasi aktor, dan analisa kebutuhan sistem. Pada tahap ini visi produk dan tujuan bisnis aplikasi dirumuskan dan diatur kembali. Hasil dari tahap ini adalah sekumpulan kebutuhan pengguna beserta prototype yang ditunjukan untuk tahap selanjutnya.

\section{b. Planning Phase (Fase perencanaan)}

Fase ini memfokuskan pada pemilihan kebutuhan yang sesuai dengan batasan-batasan yang 
dimiliki klien dan tim. Kesepakatan fase ini menghasilkan rencana rilis dan rencana iterasi. Rencana rilis adalah melampirkan fitur-fitur yang akan dikembangkan dalam jangka waktu yang telah disepakati. Rencana iterasi menghasilkan sekumpulan tahapan-tahapan yang akan dilakukan beserta keluaran yang diperoleh untuk setiap tahapan.

c. Iteration Phase (Fase pengembangan)

Dengan Fase ini dikenal juga dengan fase pengembangan solusi. Fase iterasi adalah melakukan eksekusi perencanaan iterasi melalui serangkaian aktivitas teknis seperti pembuatan arsitektur alur sistem, pembuatan kode, dan melakukan unit test untuk setiap modul. Hasil keluaran setiap iterasi dikenal dengan rilis persial atau small release.

\section{c. Production Phase (Fase produksi)}

Setelah dilakukan fase iterasi selanjutnya yaitu fase produksi. Fase ini melakukan pengujian terhadap hasil setiap iterasi. Pada fase ini dilakukan pengujian terhadap setiap iterasi yang telah ditetapkan antara peneliti dan klien yaitu pihak Kelurahan Oebufu. Pengujian tersebut tidak sama dengan proses pengujian pada fase iterasi. Pada fase ini pengujian dilakukan langsung di tempat sistem akan dipakai yaitu pada unit PC kantor Kelurahan Oebufu. Pengujian ini dikenal dengan acceptance testing (pengujian penerima) untuk mengetahui apakah sistem bekerja sesuai dengan ketentuan untuk mengatasi masalah yang ada sekarang ini. Pada tahap ini dilakukan juga verifikasi dan integrasi terhadap hasil dan rencana rilis yang ada. Hasil fase adalah sebuah solusi dites baik oleh tim maupun klien.

\section{d. Maintenance Phase (Fase pemeliharaan)}

Fase ini memfokuskan pada layanan dukungan setelah software tersebut dikembangkan. Fase ini melakukan perbaikan dari kesalahan-kesalahan yang ditemukan pada solusi serta penyesuaian kecil pada solusi, Selain itu pada fase ini dimungkinkan pula terjadi kesepakatan untuk pengembangan sistem yang lebib terperinci dan disesuaikan dengan perkembangan kebutuhan masyarakat kelurahan pada rilis selanjutnya.

\section{HASIL DAN PEMBAHASAN}

\section{Fase Explorasi (Exploration Phase)}

Pada fase ini, dilakukan observasi dan wawancara guna memahami proses administrasi dan informasi yang berjalan pada Kelurahan Oebufu untuk identifikasi aktor, kebutuhan sistem, visi produk serta tujuan dari permasalahan yang akan diselesaikan.

a. Perspektif produk

Layanan aspirasi dan informasi pada Kelurahan Oebufu merupakan sebuah aplikasi yang dibangun sebagai media yang diharapkan dapat memberikan kemudahan dalam penyebaran informasi mengenai Kelurahan Oebufu kepada pihak masyarakat dan begitu pula sebaliknya menjadi media yang dapat memfasilitasi aspirasi dari masyarakat kepada pihak kelurahan.

Layanan aspirasi dan informasi pada Kelurahan Oebufu akan dibangun berbasis Android dan SMS gateway dengan memanfaatkan web service yang mana, aplikasi berbasis Android dapat berjalan di berbagai platform smartphone Android dan untuk layanan SMS gateway dapat dijalankan pada berbagai browser. Aplikasi SMS gateway serta web service dibangun dengan menggunakan bahasa pemrograman PHP dan XAMPP yang didalamnya sudah tersedia MySQL sebagai sistem manajemen basis data, untuk spesifikasi dari web servicenya sendiri memiliki tampilan yang di paparkan serupa dengan web admin pada umumnya, namun, untuk sistem lainnya yang akan berinteraksi dengan web service yaitu aplikasi android akan terhubung sesuai dengan penggambaran arsitektur layanan aspirasi dan informasi melalui koneksi database PHP untuk mengintegrasi data yang diinputkan oleh admin untuk diupdate atau ditampilkan pada aplikasi android terkait, yang akan disampaikan menggunakan HTTP dengan serialisasi JSON.

Pengguna dari layanan aspirasi dan informasi terdiri dari 3 aktor yaitu aparatur kelurahan dan Lurah yang bertindak sebagai admin dari web service dan SMS gateway serta masyarakat Kelurahan Oebufu sebagai pengguna aplikasi berbasis android. Admin akan mengelolah data (tambah, simpan, ubah, hapus) kemudian masyarakat berinteraksi dengan sistem melalui media internet, misalnya dalam penginputan aspirasi secara langsung melalui smartphone android dan mengirimkannya kepada pihak kelurahan. Selain itu masyarakat juga dapat melihat berbagai informasi lengkap melalui pemilihan fitur-fitur yang tersedia

sesuai kebutuhan. Untuk lebih jelasnya perhatikan gambar arsitektur sistem berikut:

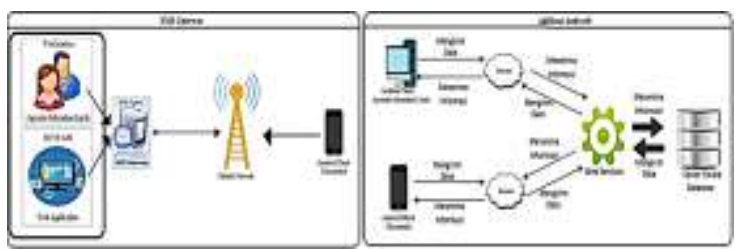

Gambar 2. Arsitektur layanan aspirasi dan informasi pada Kelurahan Oebufu 


\section{b. Kebutuhan Khusus}

Kebutuhan khusus dalam hal ini meliputi seluruh kebutuhan antarmuka eksternal pengguna dengan sistem dan kebutuhan fungsionalitas perangkat lunak. Kebutuhan antarmuka eksternal dapat dibagi menjadi tiga yaitu sebagai berikut:

1) Kebutuhan antarmuka eksternal

Kebutuhan antarmuka eksternal yaitu bagaimana perangkat lunak dapat berinteraksi dengan pengguna, perangkat keras sistem, perangkat keras luar sistem dan perangkat lunak lainnya.

2) Antarmuka pemakai

Pengguna sistem terdiri dari aparatur kelurahan/Lurah yang bertindak sebagai admin dan masyarakat sebagai pengguna sistem yang akan dibangun. Admin dapat mengakses langsung sistem melalui database yang dikoneksikan dengan web service sedangkan pengguna berinteraksi secara langsung dengan antarmuka aplikasi android untuk melihat informasi yang telah disediakan terkait kelurahan serta menginputkan aspirasi. Adapun kebutuhan perangkat keras yang digunakan yaitu sebuah perangkat komputer, smartphone android dan modem, sedangkan perangkat lunak yang digunakan yaitu web browser.

\section{Fase Perencanaan (Planning Phase)}

Pada fase ini, dilakukan pemilihan kebutuhan yang sesuai dengan kebutuhan Kelurahan Oebufu. Dengan melampirkan fitur yang akan dikembangkan dalam jangka waktu yang telah disepakati melalui sekumpulan tahapan mulai dari mengidentifikasi fungsi produk yang tersedia pada sistem, merancang alur penggunaan sistem beserta pembagian fungsi tugas dari setiap aktor yang terlibat didalamnya. Singkatnya, pada fase ini akan dilakukan tahap perancangan sistem, yang mana tahap ini merupakan tahap pendekatan awal untuk menyelesaikan sebuah masalah [19].

\section{a. Fungsi Produk}

Fungsi produk yang dimaksud meliputi seluruh fitur yang terdapat dalam sistem yang akan diakses oleh masyarakat dan dikelola oleh admin. Dalam hal ini setiap fitur dalam sistem dibagi berdasarkan aktor/pengguna, dalam hal ini untuk penentuan fungsi produk akan disesuaikan dengan model dari use case diagram yang dirancang.

\section{b. Use Case Diagram}

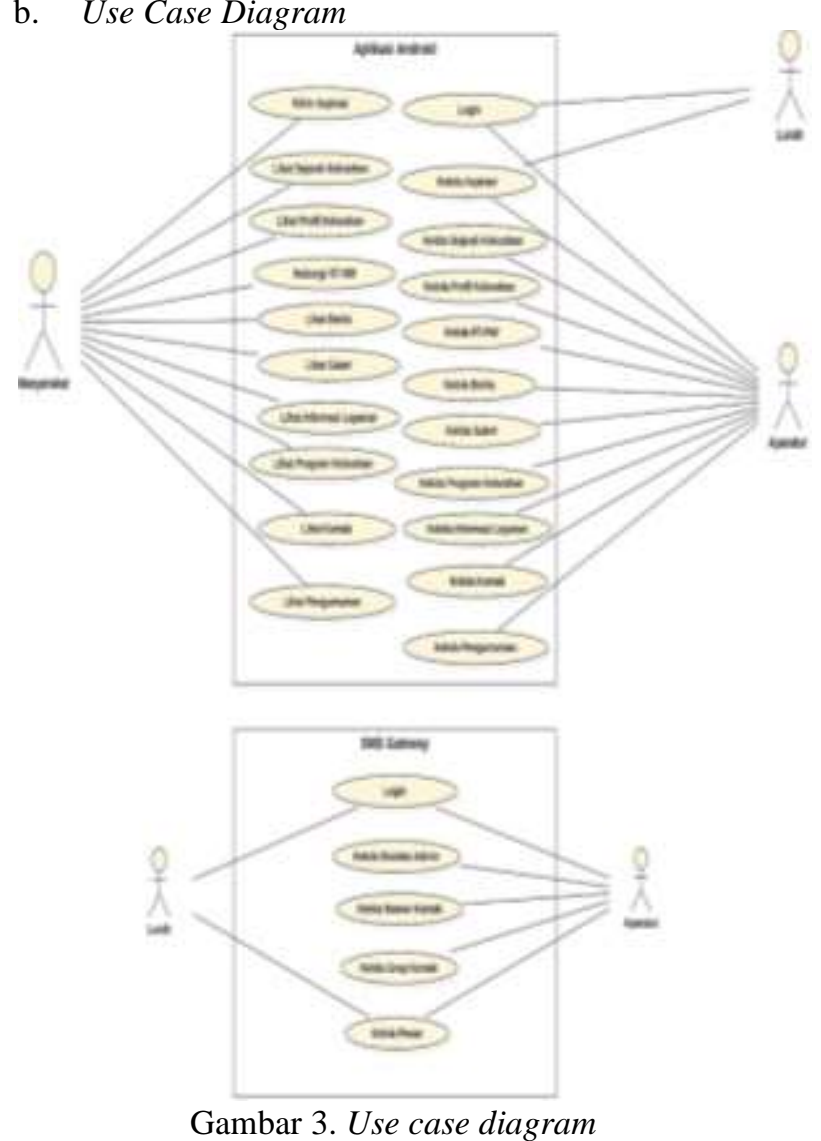

Pada use case diagram, aktor pada sistem ini yang pertama adalah Lurah yang bertindak sebagai pimpinan yang dapat mengelola aspirasi dari masyarakat mulai dari membalas serta menghapus aspirasi secara langsung melalui smartphone android serta mengelola pesan pada SMS gateway. Lalu aktor selanjutnya yaitu aparatur Kelurahan Oebufu sebagai admin dari sistem yang mengelola setiap fitur yang tersedia pada sistem mulai dari aspirasi, sejarah kelurahan, profil kelurahan, RT/RW, berita, galeri, program kelurahan, informasi layanan, kontak, pengumuman yang dikelola melalui web service serta untuk biodata admin, nomor kontak, grup kontak serta pesan dikelola melalui aplikasi SMS gateway. Selanjutnya, masyarakat dapat mengirimkan aspirasi, melihat sejarah kelurahan, profil kelurahan, RT/RW, berita, galeri, program kelurahan, informasi layanan, kontak, dan pengumuman terkini yang tersedia melalui smartphone android. 
c. Arsitektur Layar

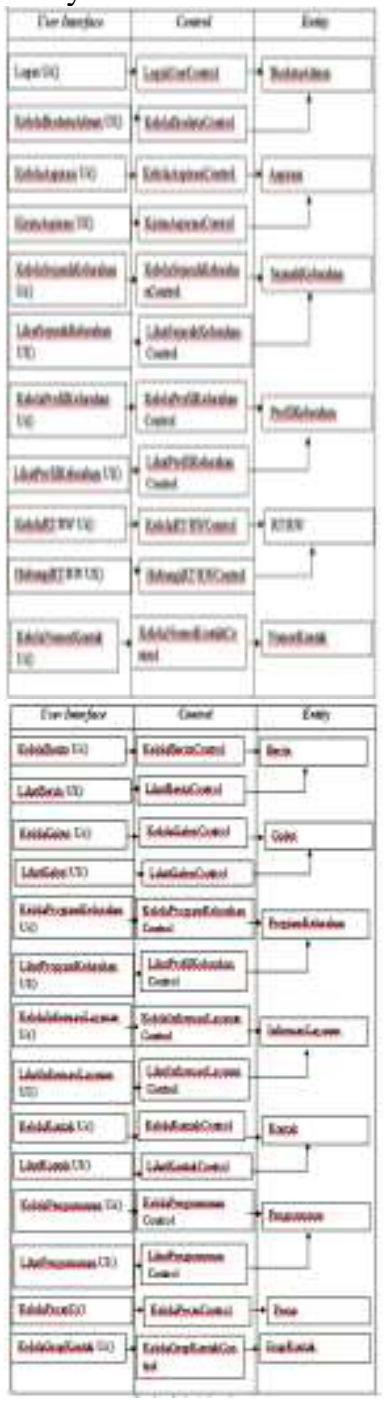

Gambar 4. Arsitektur layar

\section{d. Class Diagram}

Class Diagram adalah diagram yang menunjukan kelas yang ada dari sebuah sistem dan hubungannya secara logika, class diagram ini menggambarkan struktur statis sebuah sistem [20].

Pada class diagram yang dirancang terdiri dari 15 class yakni class biodata admin, profil kelurahan, sejarah kelurahan, informasi layanan, program kelurahan, aspirasi, galeri, detail galeri, berita, kontak, pengumuman, nomor kontak, grup kontak, RT/RW dan pesan. Adapun class diagram dapat dilihat pada gambar berikut:

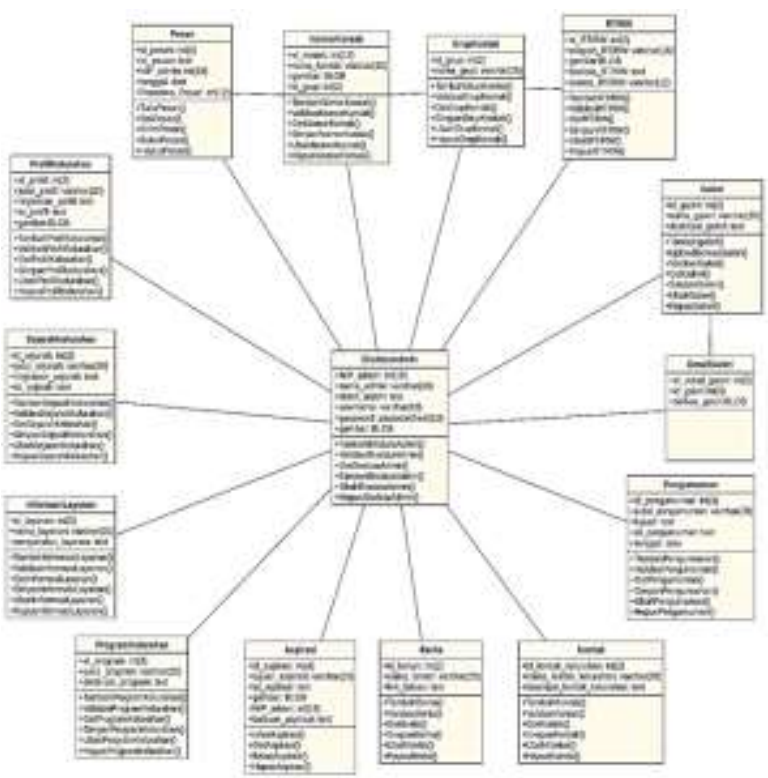

Gambar 5. Class diagram

e. Perancangan Antarmuka

Perancangan Antarmuka untuk layanan aspirasi dan informasi pada Kelurahan Oebufu dibagi dalam 3 bentuk perancangan antarmuka untuk setiap kebutuhannya dalam hal ini antarmuka aplikasi android yang akan diakses oleh semu aktor, antarmuka web service serta antarmuka SMS gateway yang dapat diakses oleh pihak aparatur kelurahan sebagai admin sistem serta Lurah Oebufu sebagai pimpinan, setiap perancangannya akan dijabarkan sebagai berikut:

1) Perancangan antarmuka aplikasi android

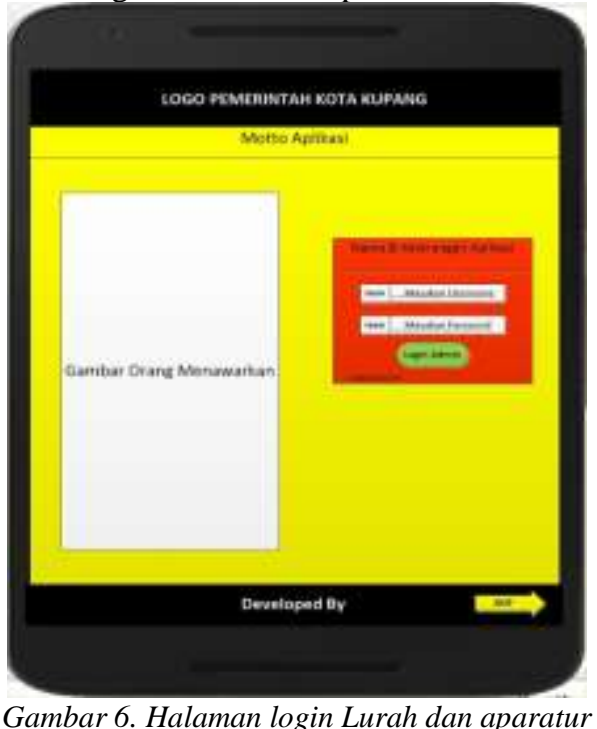

Gambar 6. Halaman login Lurah dan aparatur 
ISSN 2477-0043

e-ISSN 2460-7908

Antarmuka login admin berfungsi bagi pihak admin dan lurah dari sistem. Melalui antarmuka ini admin memulai proses login dan kemudian masuk kedalam sistem aplikasi android, dengan cara menginputkan username dan password.

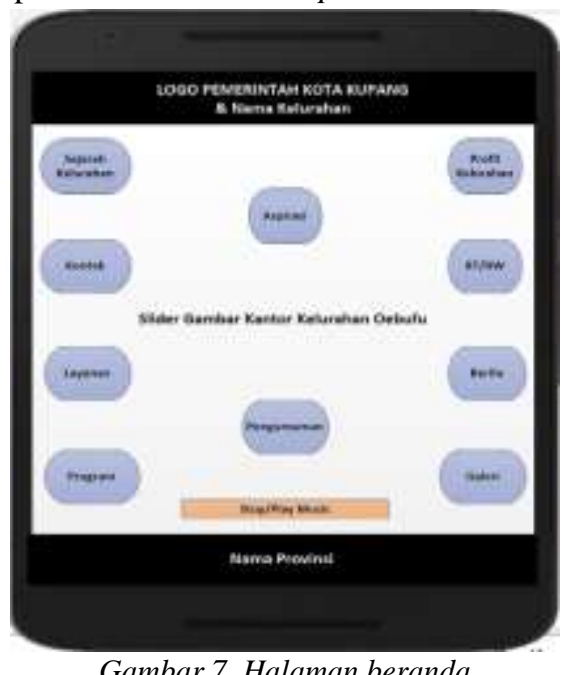

Gambar 7. Halaman beranda

Antarmuka beranda ini berfungsi sebagai tampilan awal saat admin telah berhasil memasuki sistem yang mana pada antarmuka ini menampilkan pilihan untuk melihat berbagai informasi dan mengakses layanan yang tersedia.

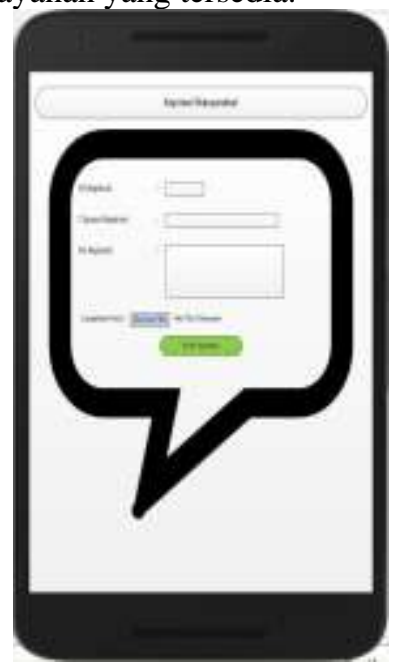

Jurnal Teknologi Terpadu

Vol. 5, No. 2, Desember 2019

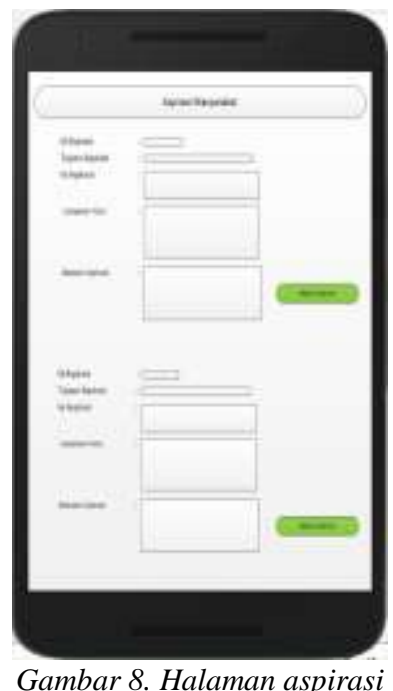

Antarmuka aspirasi ini berfungsi sebagai tampilan yang muncul saat pengguna aplikasi ingin mengirimkan aspirasinya kepada pihak kelurahan, dan juga sebaliknya bagi pihak kelurahan untuk membalas aspirasi masyarakatnya.

2) Perancangan antarmuka web service

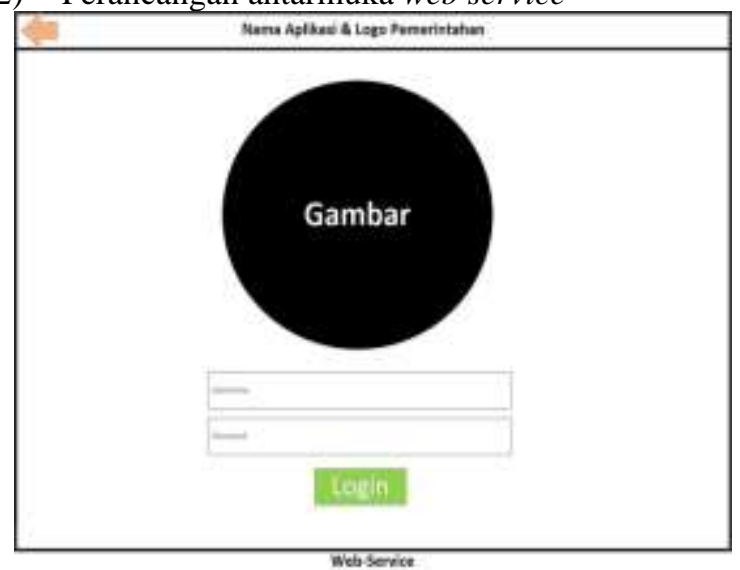

Gambar 9. Halaman login Lurah dan aparatur

Antarmuka login admin berfungsi bagi pihak admin dari sistem. Melalui antarmuka ini admin memulai proses login dan kemudian masuk kedalam sistem web service, dengan cara menginputkan username dan password. 
ISSN 2477-0043

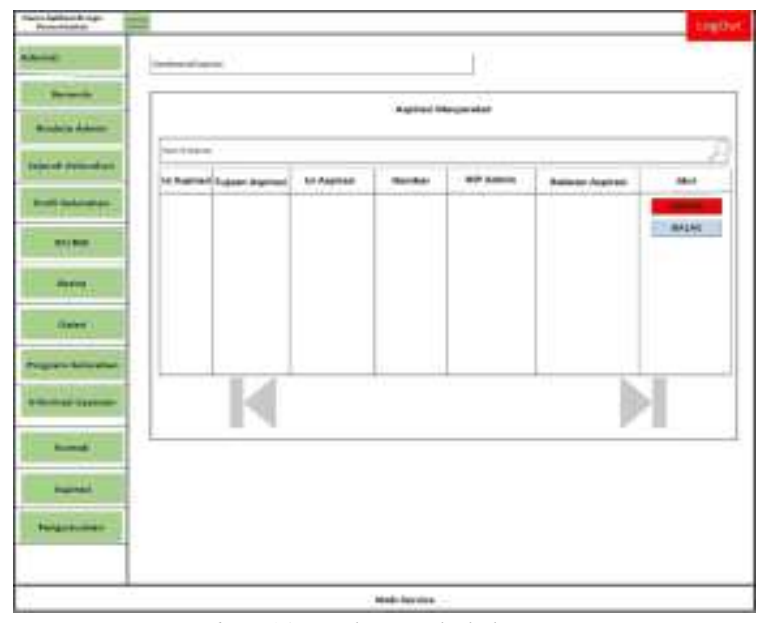

Gambar 10. Halaman kelola aspirasi

3) Perancangan antarmuka SMS gateway

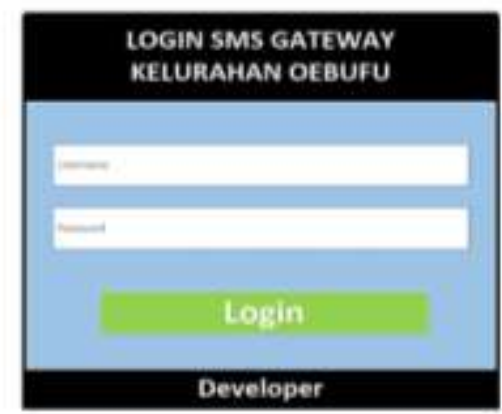

Gambar Kanter Kelurahan Oebufu

Gambar 11. Halaman login Lurah dan aparatur

Antarmuka login admin berfungsi bagi pihak admin dari sistem SMS gateway. Melalui antarmuka ini admin memulai proses login dan kemudian masuk kedalam sistem, dengan cara menginputkan username dan password.

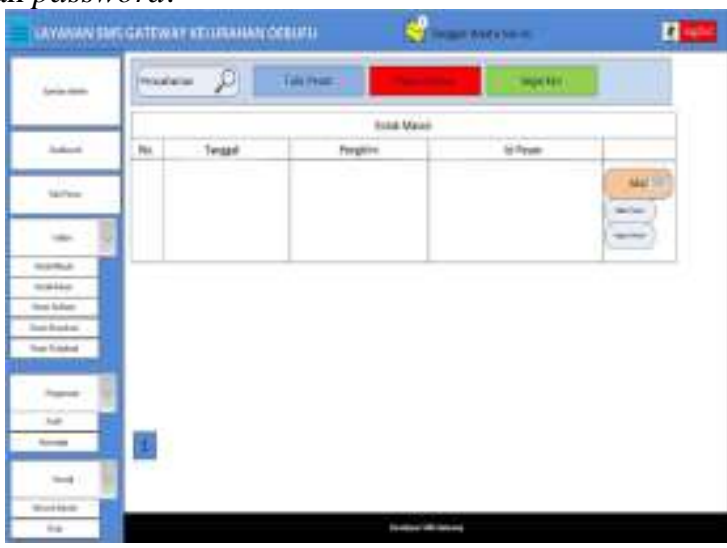

Gambar 12. Halaman kotak masuk

Antarmuka kotak masuk berfungsi sebagai tampilan saat admin ingin melihat daftar pesan masuk pada sistem.
Jurnal Teknologi Terpadu Vol. 5, No. 2, Desember 2019

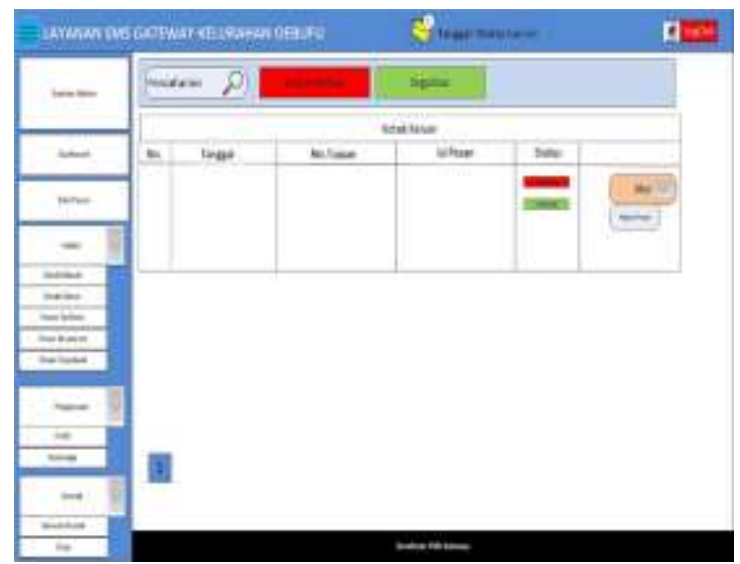

Gambar 13. Halaman kotak keluar

Antarmuka kotak keluar berfungsi sebagai tampilan saat admin ingin melihat daftar pesan keluar pada sistem.

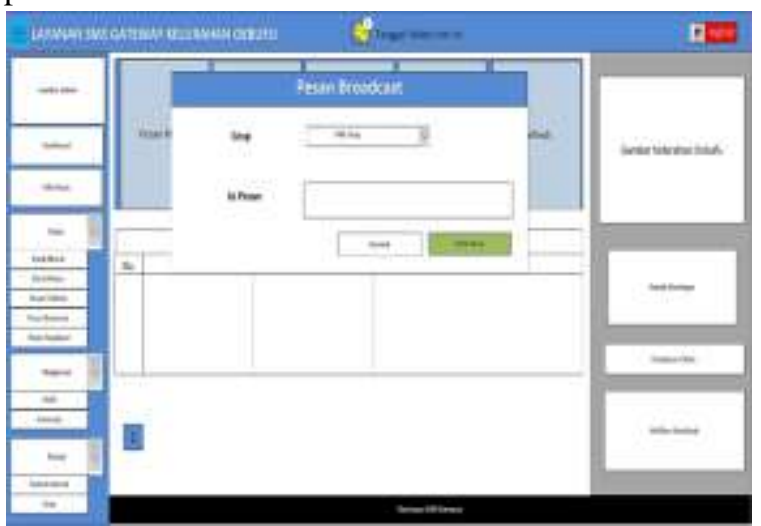

Gambar 14. Halaman pesan broadcast

Antarmuka pesan broadcast berfungsi sebagai tampilan saat admin ingin melihat mengirimkan pesan broadcast atau satu pesan kepada banyak eneria sekaligus melalui sistem.

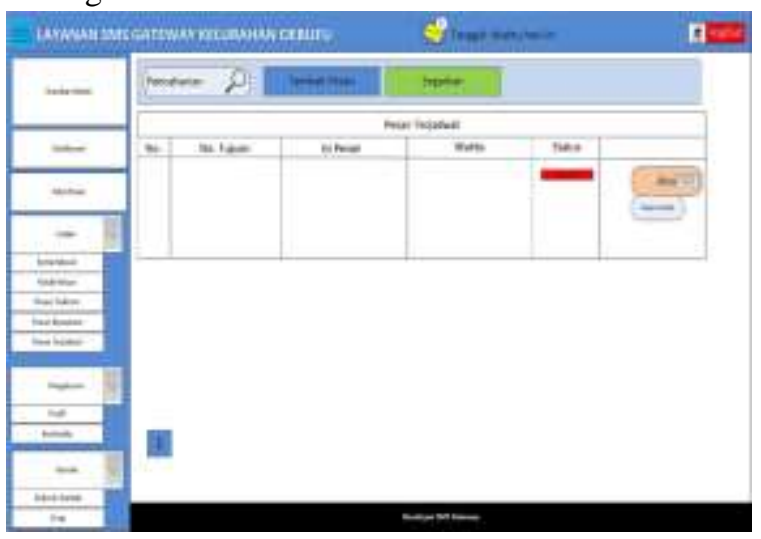

Gambar 15. Halaman pesan terjadwal

Antarmuka pesan terjadwal berfungsi sebagai tampilan saat admin ingin melihat daftar pesan yang telah dijadwalkan pada sistem. 
ISSN 2477-0043

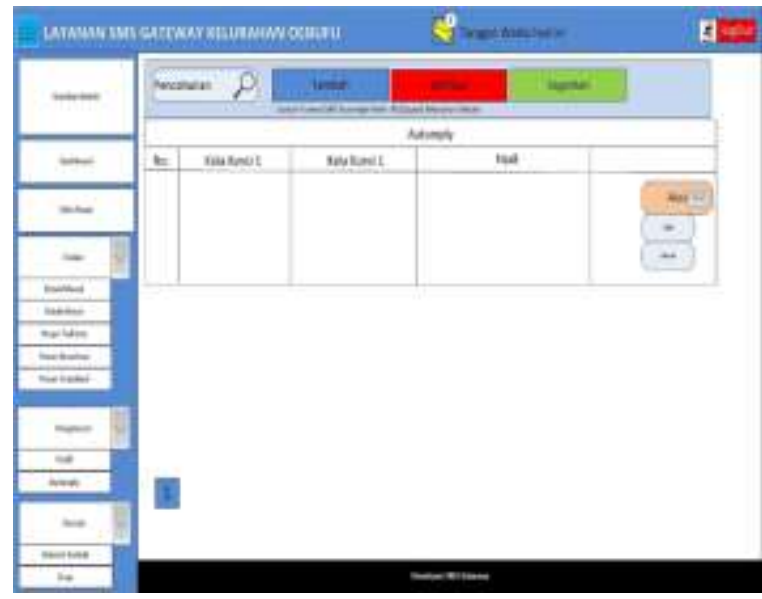

Gambar 16. Halaman autoreply

Antarmuka ini berfungsi sebaga tampilan saat admin ingin melihat dan menambah dan mengelola daftar pesan autoreply atau pesan otomatis yang ada.

\section{KESIMPULAN}

Perancangan ini menjadi dasar untuk pengembangan sistem layanan aspirasi dan informasi kedepannya guna mengatasi masalah yang tengah terjadi untuk memenuhi kebutuhan Kelurahan Oebufu.

Penelitian ini menerapkan model Global eXtreme Programming (GXP), akan tetapi untuk sementara dibatasi sampai pada fase perencanaan saja. Selanjutnya diharapkan hasil perancangan dapat diimplementasikan pada Kelurahan Oebufu guna membantu pihak Kelurahan Oebufu dalam penyampaian informasi terkini terkait kelurahan kepada masyarakat setempat serta dapat mempermudah masyarakat dalam penyampaian aspirasi kepada pihak kelurahan.

\section{REFERENSI}

[1] A. Sujata, B. Masthuri, Winarso, DD. Fernandes \& S. Widyawati, Ombudsman Indonesia Masa Lalu, Sekarang, dan Masa
Jurnal Teknologi Terpadu

Vol. 5, No. 2, Desember 2019

Mendatang, Komisi Ombudsman Nasional, Jakarta, 2002.

[2] FMH. Tjiptabudi, "Perencanaan Arsitektur Sistem Informasi Keimigrasian Pada PLBN Terpadu Di NTT", Journal Informatic Technology And Communication (JITU), vol. 3, no. 1, pp. 11-19, 2019.

[3] Pusat Bahasa Departemen Pendidikan Nasional, Kamus Besar Bahasa Indonesia, Balai Pustaka, Jakarta, 2003.

[4] B. Istariyani, Pengaruh Kualitas Pelayanan Terhadap Kepuasan Pelanggan PT. TELKOM Cabang Sragen. FE UMS, Sragen, 2002.

[5] MA. Hoetomo, Kamus Lengkap Bahasa Indonesia, Mitra Pelajar, Surabaya, 2005.

[6] Slameto, Belajar dan Faktor-faktor yang Mempengaruhinya, Rineka Cipta, Jakarta, 2003.

[7] E. Turban, Decision Support Systems and Intelligent Systems, Edisi 7, Andi, Yogyakarta, 2005.

[8] R. McLeod \& HT. Schell, Sistem Informasi Manajemen, Edisi 8. PT. Indeks, Jakarta, 2004.

[9] N. Safaat, Pemrograman Aplikasi Mobile Smartphone Dan Tablet PC Berbasis Android, Informatika, Bandung, 2015

[10] PA. Merditawati, MM. Hidayat \& RF. Tias, "Decision Support System For Selecting Tourism Object In Surabaya City Using Simple Additive Weighting Based On Android", Journal of Electrical Engineering and Computer Sciences, vol. 3, no. 1, 2018.

[11] M. Sadeli, Aplikasi SMS dengan Visual Basic 6.0 dan Visual Basic 2010, Maxikom, Palembang, 2012.

[12] A. Saputra, Membangun Aplikasi Bioskop Dan SMS Untuk Panduan Skripsi. PT. Elex Media Komputindo, Jakarta, 2013.

[13] S. Pramsane \& R. Sanjaya "Mobile Education Services Based on SMS and Their Architecture Comparison", Proceeding of Third International 